\title{
The Battle of the Styles in Architectural 'Graffiti'
}

by GAVIN STAMP

In Ornament and Crime Adolf Loos compared architectural decoration with the scriblings on lavatory walls; graffiti recently discovered on a basement wall in Cambridge provide a curious comment on one of the architectural controversies of Victorian England.

In $1976 \mathrm{Mr}$ Christopher B. George of Emmanuel College, Cambridge, came across pencilled drawings behind old shelving on the plaster walls of a long disused basement storeroom in No. 22 Parkside, an Early Victorian house on the east side of Parker's Piece. ${ }^{1}$ As well as scribbled calculations and an unidentifiable rough plan, there were caricature drawings of a mongrel-styled building with a Classical portico and a Gothic tower, labelled 'What Palmerston wants for the Foreign Office. Hardwick would have done it better, but he's dead', and of a huge statue, labelled 'Albert the Good, but he's dead too. G.G.S.' (Pl. 60).

Either these graffiti are an elaborate and puzzling hoax to fool architectural historians or they must constitute a contemporary reference to the controversy over the style of the new Government Offices in London which raged between 1857 and I863. 'G.G.S.' are the initials of the eventual architect of the building (which included the Foreign Office), that is George Gilbert Scott, and also of his eldest son, G. G. Scott Junior, who had strong Cambridge connections.

The elder Scott is unlikely to have scribbled on basement walls; his son might have done. Having served his articles in the 'Spring Gardens Academy' between I 857 and I 860, G. G. Scott Junior supervised several restoration jobs for his father as he showed particular ability in this field. One obituarist recorded that he was sent to Cambridge to look after several jobs and while there old Eton friends persuaded him to enter the University. ${ }^{2}$ In 1863 he entered Jesus College and in 1866 graduated head of the Moral Science Tripos. In 1872 Scott became, briefly, a Fellow of Jesus. Extensive work at Peterhouse was carried out in 1867-70 entirely by the younger Scott although in his father's name at first.

Several Scott commissions in Cambridge ran concurrently with the Government Offices affair: the repairs to the roof of King's College Chapel, i 86 I- $-6_{3}$, the restoration and enlargement of the medieval parts of the Old Schools, $1864-67$ and the enlargement of the hall and the building of a new chapel at St John's, $1863-69$. Scott reported on the extensive proposed works at St John's in 1862 ; very possibly his son could have conducted the preliminary surveys. The younger Scott may have been the first to comment on the discrepancy between the pattern of the fan-vault and the number 


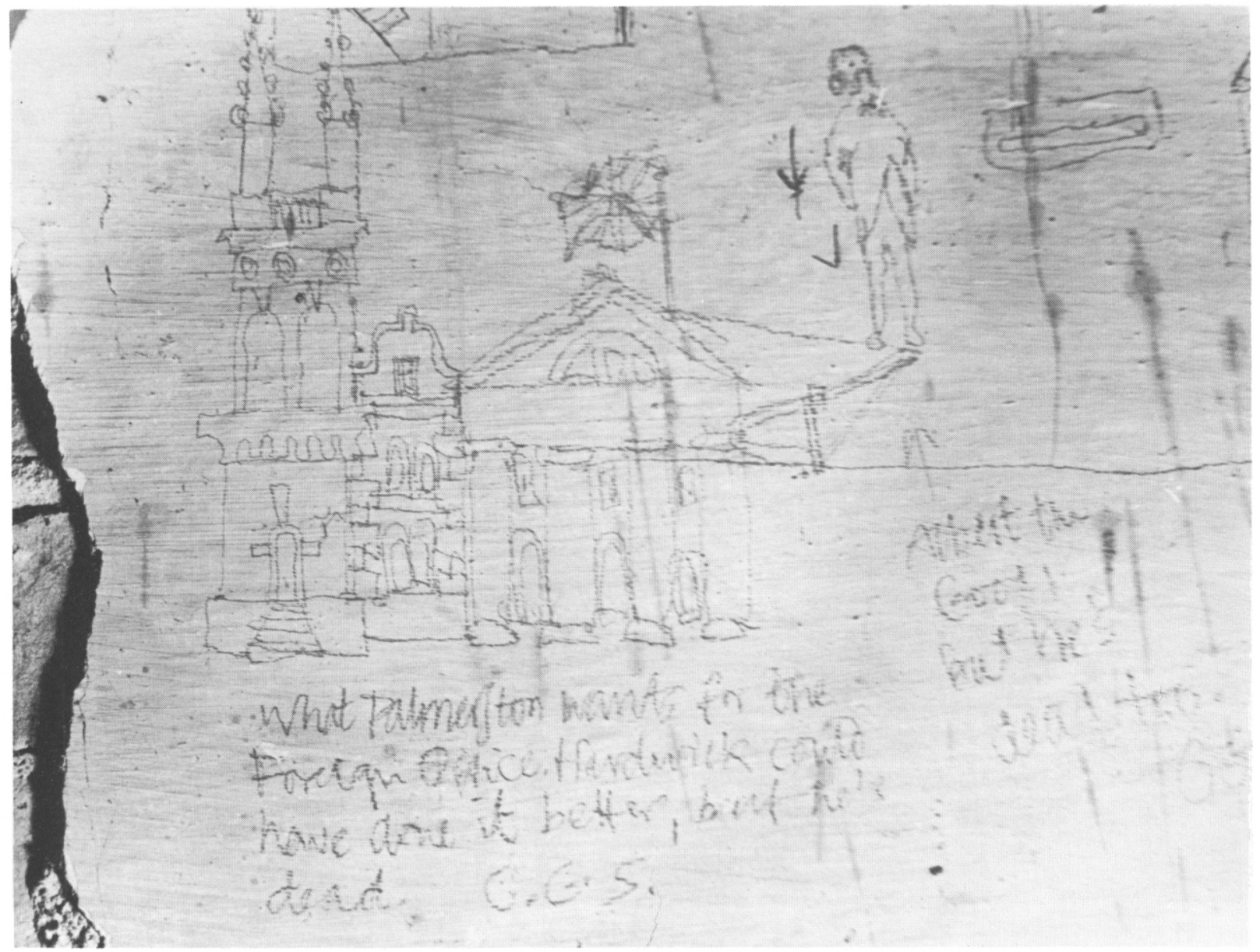

Pl. 60 Graffiti in basement, 22 Parkside, Cambridge (discovered 1976) 
of ribs in the wall-shafts in the choir of King's College Chapel; possibly he noticed this while supervising the repairs. ${ }^{3}$

In the back garden of No. 22 Parkside, which is called Inveruglas House, are fragments of medieval masonry said to come from the Old Chapel of St John's which was demolished in 1869 when Scott's new building was finished. There seems to be no documentary record of this, nor for any reason for the transfer of the relics. ${ }^{4}$ The owner of the property from I 847 until 1869 was George Cockle, a Cambridgeshire gentleman. Possibly he let rooms to the younger Scott or, perhaps, to the clerk of works acting at St John's.

Scott's Gothic design for the new Government Offices was rejected by the Prime Minister, Lord Palmerston, towards the end of I 859 ; his compromise 'Byzantine' scheme was dismissed by Palmerston as 'neither one thing nor t'other - a regular mongrel affair' in September 1860. The final executed Classical design, for which Scott 'bought some costly books on Italian architecture', was approved by the Prime Minister and voted by Parliament in July i 86r. Construction work on the Foreign and India Offices did not commence until I $86_{3}$; possibly in the meantime the architect still retained hopes of building in Gothic. ${ }^{5}$

The graffiti could date from I 862. The inscription implies the continuing interfering existence of Palmerston, who died in 1865 , while Prince Albert died on 14 December, I86I - Scott, Senior, of course, was to design his memorial and in a rather different form from that sketched on the basement wall. The anachronism is the reference to Hardwick, who must be Philip Hardwick, a distinguished classicist, who did not, in fact, die until 1870 . However, he had been seriously ill since 1847 and totally retired from public life in $186 \mathrm{x}$ : possibly the author of the graffiti assumed he was dead. ${ }^{6}$

These graffiti could have been an ironical comment on Scott's much criticized changes in style to keep a job made by someone with a knowledge of the architectural scene; if the initials 'G.G.S.' were genuine, then they could have been a humorous comment by the younger Scott on the difficulties of his father, for George Gilbert Scott Junior is known to have had a sense of humour. ${ }^{7}$ The circumstances behind the caricatures on the wall must remain a matter for conjecture: perhaps the basement was a wine cellar. The graffiti have now necessarily been destroyed.

NOTES

I I am very grateful to Mr George and to Edwin Foxton, then Domestic Bursar of Emmanuel College, for bringing these graffiti to my attention and for having them photographed. They are reproduced here by kind permission of Emmanuel College, Cambridge.

2 British Architect (14 May 1897), p. 34x.

3 The design is analysed in Scott's Essay on the History of English Cburch Architecture (188 I), Pp. I 8 I-85. 4 Mr Foxton was told this by Mrs Wright, from whom the College bought the property. Oak panelling in a ground floor room is also said to have come from St John's.

5 For the history of the Government Offices designs, see Scott's Personal \&o Professional Recollections (I879), pp. I77-20I, which was discussed in Arcbitectural History, xix (1976), pp. 57-58, and the note in the Scott Family volume of the RIBA Drawings Collection catalogue p. 58. ,

6 H. Colvin, A Biograpbical Dictionary of British Arcbitects, 1600-1840 (1978), p. 387 ; Hermione Hobhouse in Seven Victorian Architects (1976), p. 40.

7 Scott filled a notebook with humotous stories and anecdotes which is now at the RIBA. When he was incarcerated in the Bethlem Hospital in 1883 , the case notes record that he was "very jolly and amusing.' His defence plea in the lunacy trial the following year was 'alcoholic mania'. 